\title{
Adiposity, type 2 diabetes and Alzheimer's disease
}

\author{
José A. Luchsinger, MD MPH ${ }^{1,2,3,4}$ and Deborah R. Gustafson, MS PhD 5,6 \\ ${ }^{1}$ Gertrude H. Sergievsky Center, Columbia University, New York, NY \\ ${ }^{2}$ Taub Institute for Research of Alzheimer's Disease and the Aging Brain, Columbia University, New York, \\ NY \\ ${ }^{3}$ Division of General Medicine, Department of Medicine, Columbia University College of Physicians and \\ Surgeons, New York, NY \\ ${ }^{4}$ Department of Epidemiology, Joseph P. Mailman School of Public Health, Columbia University, New York, \\ NY \\ ${ }^{5}$ Institute of Neuroscience and Physiology, Section for Psychiatry and Neurochemistry, Sahlgrenska Academy \\ at the University of Gothenburg, Sweden
}

${ }^{6}$ Medical College of Wisconsin, Department of Family and Community Medicine, Milwaukee, Wisconsin, USA

\begin{abstract}
This manuscript provides a comprehensive review of the epidemiologic evidence linking the continuum of adiposity and type 2 diabetes (T2D) with Alzheimer's disease (AD). The mechanisms relating adiposity and T2D to AD may include hyperinsulinemia, advanced products of glycosilation, cerebrovascular disease, and products of adipose tissue metabolism. Elevated adiposity in middle age is related to a higher risk of AD but the data on this association in old age is conflicting. Several studies have shown that hyperinsulinemia, a consequence of higher adiposity and insulin resistance is also related to a higher risk of $\mathrm{AD}$. Hyperinsulinemia is a risk factor for T2D, and numerous studies have shown a relation of $\mathrm{T} 2 \mathrm{D}$ with higher $\mathrm{AD}$ risk. The implication of these associations is that a large proportion of the world population may be at increased risk of $\mathrm{AD}$ given the trends for increasing prevalence of overweight, obesity, hyperinsulinemia, and T2D. However these associations may present a unique opportunity for prevention and treatment of AD. Several studies in the prevention and treatment of T2D are currently conducting or have planned cognition ancillary studies. In addition, clinical trials using insulin sensitizers in the treatment or prevention of $\mathrm{AD}$ are under way.
\end{abstract}

\section{Keywords}

adiposity; overweight; obesity; hyperinsulinemia; insulin; glucose; type 2 diabetes; alzheimer's disease; cognitive impairment

Correspondence/Requests for reprints: José A. Luchsinger, MD, 630 West $168^{\text {th }}$ St., PH19, New York, NY 10032, Telephone:

212-305-4730, Fax: 212-305-2526, E-mail: E-mail: jal94@ columbia.edu.

Conflicts of interest: Dr. Luchsinger has no conflicts of interest to report.

Dr. Gustafson has no conflicts of interest to report. 


\section{Introduction}

\section{Burden of Alzheimer's disease}

Alzheimer's disease (AD) is the most common form of dementia, accounting for between $70 \%$ to over $90 \%$ of all cases [1], and its prevalence is expected to quadruple by the year 2047 in the United States [2]. As much as 50\% of the population aged 85 years and older, the fastest growing segment of the population, may have $\mathrm{AD}$ [3]. The risk factors for $\mathrm{AD}$ can be classified as genetic and non-genetic. Three genes have been identified in familial early onset AD, Amyloid Precursor Protein (APP), Presenilin 1, and Presenilin 2 [4]. These genes affect less than $5 \%$ of cases of $\mathrm{AD}$, have full penetrance and expressivity, and usually affect persons in middle age [5]. This review will address risk factors for late onset AD. Robust risk factors that have been identified for late onset AD include older age, lower education, and the APOE- $\varepsilon 4$ allele[5]. Importantly, APOE 44 has been found to modulate the effect of other putative risk factors [6], such as type 2 diabetes (T2D) and hyperinsulinemia [7,8]. Current treatment options for $\mathrm{AD}$ only address symptoms, and no treatments are available that focus on delaying the actual disease process [9]. One of the currently accepted hypotheses of the pathogenesis of AD is that the main culprit is the accumulation of amyloid $\beta$ in the brain, resulting in synapse disruption and neuronal destruction [4,10]. Mild Cognitive impairment (MCI) has been used to describe a transitional state between normal cognitive function and $\mathrm{AD}$ dementia $[11,12]$, and has thus been targeted for interventions [13]. Individuals with MCI do not have dementia but have memory complaints without loss of function in their daily activities[12]. While general cognitive performance is well preserved, memory performance on standardized tests falls below expectations for age and education. Persons with MCI progress to AD at the rate of nearly $10 \%$ to $15 \%$ per year [11] compared to 1 to $2 \%$ in elderly persons with normal cognition [12]. MCI can be classified in amnestic and non-amnestic MCI. It is believed that amnestic $\mathrm{MCI}$ is an early stage of $\mathrm{AD}$, while non-amnestic MCI, such as executive MCI, is less specific to $\mathrm{AD}[11]$. The prevalence of amnestic MCI varies between 3\% and 20\% depending on the criteria applied [14], and increases from about $1 \%$ in persons 60 years old to $25 \%$ at age 85 [15]. AD can be studied in epidemiologic studies through the outcomes of memory impairment or decline, amnestic MCI, and Alzheimer's dementia, and this review will cover evidence examining these outcomes.

\section{The continuum of adiposity, hyperinsulinemia, and type 2 diabetes}

There is a concerning epidemic of obesity, insulin resistance and T2D in the world [16]. With the aging of the population and greater longevity, the long term consequences of these conditions will have a significant public health impact in elderly populations. Adiposity refers to the amount of adipose (fat) tissue in the body [17]. Adiposity is a continuum, and the normal or ideal threshold of adiposity is not clear. However, as adiposity increases it is associated with higher risk of insulin resistance, T2D, hypertension, dyslipidemia, cardiovascular disease, degenerative joint disease, cancer, and respiratory diseases [18,19]. Definitions of a elevated levels of adiposity have been devised using existing measures and according to their relationship with adverse outcomes[20]. Adiposity is usually measured indirectly with anthropological measures[21] such as the body mass index (BMI), defined as weight in kilograms divided by height in meters squared $\left(\mathrm{k} / \mathrm{m}^{2}\right)$. BMI is strongly correlated with total body fat tissue and is a good indirect measure of adiposity [19], although this correlation decreases in older age [22]. Another commonly used measure of adiposity is waist circumference. Waist circumference is meant to measure the accumulation of adipose tissue in the abdomen, the largest depot of adipose tissue, and thus, perhaps it is a more direct measure of adiposity compared to BMI $[21,23]$.

Elevated waist circumference is also related to a higher risk of T2D, hypertension, dyslipidemia, and heart disease, and some studies have shown that it is a better predictor of 
adverse cardiovascular outcomes compared to BMI [24], and some have advocated its use as the best measure of adiposity [21]. A commonly used cutoff to define elevated waist circumference is $102 \mathrm{~cm}$ for men and $88 \mathrm{~cm}$ for women [24]. Other less frequently used anthropologic measures of adiposity include skinfolds and waist to hip ratio [21]. Overweight and obesity [25] and elevated waist circumference[26] are increasing in adults in the United States. More concerning, these trends are also observed in children and adolescents [27]. Two thirds of the United States population are overweight or obese [27]; 30\% are obese, and the prevalence of obesity is higher in women than men.

Insulin sensitivity is the ability of insulin to dispose of a glucose load. Insulin resistance refers to the resistance of tissues that dispose of glucose to the actions of insulin. Insulin resistance results in an increase in insulin secretion in the pancreas in order to overcome that insulin resistance. Fasting insulin levels are used in epidemiological studies as indicators of the risk of T2D [28-31]. Fasting insulin is accepted as a measure of insulin resistance that is highly correlated with more complicated measures of insulin resistance such as the euglycemic clamp [32], and the homeostasis model assessment [33].

Glucose intolerance and T2D are abnormal elevations of blood glucose that put people at risk for microvascular (nephropathy, neuropathy, retinopathy) and macrovascular disease (coronary artery disease, cerebrovascular disease, peripheral vascular disease)[34]. It is important to point out that this review addresses type 2 diabetes, not type 1 diabetes. The American Diabetes Association currently defines diabetes as a fasting glucose elevation $>126$ $\mathrm{mg} / \mathrm{dl}$, and glucose intolerance as an elevation of glucose between 110 and $126 \mathrm{mg} / \mathrm{dl}$ [35]. It is difficult to establish an absolute threshold for the definition of glucose intolerance and diabetes. Previously, the definition of diabetes was a fasting glucose $>140 \mathrm{mg} / \mathrm{dl}$, and people currently defined as having diabetes were then considered non-diabetic [36]. The fasting glucose threshold for the diagnosis of diabetes will change again and persons currently considered to have glucose intolerance will be considered to be diabetic. This underlines the caveats of using cutoffs to define conditions that have continuous (linear or non-linear) associations with disease: depending on the cutoff use, persons at risk may be classified as normal or abnormal (and vice versa). This is true for measures of adiposity, insulin resistance, and measures of glucose tolerance.

Adiposity, hyperinsulinemia, glucose intolerance, and T2D, are often treated as separate constructs. However, they are related sequentially and often occur simultaneously, and understanding this relationship is fundamental in the study of the role of adiposity, insulin resistance, and T2D in Alzheimer's disease. Keeping glucose in normal levels is achieved by the balance between the ability of peripheral tissues (muscle, adipose tissue, liver) to take glucose into cells, and the pancreas' ability to secrete insulin, the hormone in charge of glucose tissue uptake [34]. Thus, abnormal glucose levels are caused by a resistance of tissues to the action of insulin (insulin resistance), and by the pancreas' inability to secrete enough insulin at normal levels or higher than normal insulin levels (hyperinsulinemia) to overcome insulin resistance in tissues [37]. Insulin resistance increases with age, and the organism maintains normal glucose levels as long as it can produce enough insulin (hyperinsulinemia). Some individuals are less capable than others to mount sustained hyperinsulinemia and will develop glucose intolerance and T2D [37]. Other individuals with insulin resistance will maintain normal glucose levels at the expense of hyperinsulinemia but their pancreas will eventually "burn out", will not be able to sustain hyperinsulinemia, and will develop glucose intolerance and T2D [37]. Others will continue having insulin resistance, may have or not have glucose intolerance, will not develop T2D, but will have hyperinsulinemia and suffer its consequences. The most frequent modifiable determinant of insulin resistance and hyperinsulinemia is elevated adiposity $[17,38]$, although adipose tissue is not the only factor. Insulin resistance can reside in other tissues, including muscle, liver, and the pancreas itself [39]. The susceptibility 
to adiposity, that is, the risk of developing insulin resistance and T2D in response to adiposity, varies by gender [19] and particularly by ethnicity. For example, Chinese and southeast Asians are more susceptible than Europeans to developing insulin resistance with comparable increases of adiposity [17]. The distribution of factors related to insulin resistance and the metabolic syndrome, including adiposity, is different in Whites and Blacks [40]. Thus, conventional ways to classify adiposity may not capture its relation with adverse outcomes and this should be taken into account. High adiposity and hyperinsulinemia are both accompanied by dyslipidemia, hypertension, and inflammation [38], and these should also be taken into account.

An implication of the continuum described above is that when an epidemiologic study finds a relation between the components of this continuum and AD we cannot be certain if we are looking at a surrogate marker of one of the other components (e.g. T2D is a marker of past adiposity or hyperinsulinemia, obesity is a marker of hyperinsulinemia) or if the important exposure is the one we are examining. The answer could be that there is an aggregate effect of all the components of the continuum. The metabolic syndrome, an increasingly popular term in clinical practice and research, and reported to be associated with a higher risk of cognitive decline [41] is a constellation of adiposity, hypertension, glucose intolerance, and dyslipidemia, that is associated mainly with insulin resistance and hyperinsulinemia $[42,43]$. However, the definition of the metabolic syndrome is somewhat arbitrary, intended to capture the clustering of cardiovascular risk factors particularly in middle aged populations, and its validity in elderly populations at risk for AD is not clear [43]. The difficulty of arriving at precise metabolic syndrome criteria is reflected by the fact that over the years at least 6 different definitions have been developed that share several characteristics [42].

\section{Summary of prospective epidemiological studies linking adiposity, hyperinsulinemia, and diabetes to Alzheimer's disease}

Adiposity

Elevated BMI in middle age may be associated with higher dementia risk $[44,45]$. A recent study showed that central adiposity in middle age was related to a higher risk of dementia in older age[46]. Higher BMI at ages 70, 75 and 79 years may also predict higher dementia risk [47]. However, there have been reports of no association at mid-life [48] and of lower BMI related to higher $\mathrm{AD}$ risk $[49,50]$ at older ages. There are several explanations for this apparent paradox. First, age of the adiposity measure in relationship to clinical dementia onset varies across studies. Throughout life, there may exist critical periods in which risk or protective factors may have more or less impact. Second, several studies have reported weight loss preceding dementia onset [48,51], and may precede diagnosis by decades[52]. Understanding the reverse causality observed for adiposity parameters in relationship to dementia onset, [53], is critical for interpretation of study findings. Third, the inclusion of different birth cohorts across studies introduces the possibility of cohort effects. According to developmental origins hypotheses early life events related to birth cohort may influence both adult adiposity and cognition throughout adult life[54]. Fourth, anthropometric characteristics of populations vary around the world. If baseline BMI, whether measured at mid-life or late-life, is within a healthy range (e.g., $<25 \mathrm{~kg} / \mathrm{m} 2$ ), with low prevalence of overweight and obesity, the risky effects of high adiposity may be less likely observed. Fifth, diagnosis of dementia is not the same across epidemiologic studies. For example, some studies use neuropsychiatric interviews, some registry data, and others, screening criteria prior to diagnosis. Related to this is that demented populations are heterogeneous and identified at different levels of severity. Given the potentially rapid changes that occur in BMI throughout the dementia process, these nuances may translate to differences in observations, and thus data interpretation. Sixth, dementia is a syndrome. Metabolic alterations occurring with dementia may vary based on expression of the 
syndrome. Finally, another potential explanation is ethnicity. One study in Japanese Americans showed no association of high adiposity with AD [48]. A study in Northern New York City [55] found that in younger elderly (65 to 76 years of age), the association between BMI quartiles and $\mathrm{AD}$ resembles a $\mathrm{U}$ shaped-curve, while in the oldest old (> 76 years) higher BMI is related to a lower AD risk. This $\mathrm{U}$-shaped association has been reported for the relation between adiposity and cardiovascular mortality [56] and underscores the difficulty in studying the effects of adiposity in older age[57]. This study also found that higher waist circumference is related to higher AD risk in the younger elderly, but not in the oldest old. The Cardiovascular Health Study recently reported that elevated self-reported BMI at age 50 years was associated with a higher risk of dementia, while BMI at age 65 or older in the same individuals did not[58]. This study underscores the importance of the period in life at which adiposity is ascertained in relation to dementia. The most important explanation for the paradox linking low weight in old age to dementia seems to be weight loss. The mechanisms for this are not entirely clear. They may include loss of olfaction[59,60], one of the earliest manifestations of AD, which may lead to decreased caloric intake, forgetfulness of meals [54], and metabolic changes related to $\mathrm{AD}$ that are not well understood. In this regard, $\mathrm{AD}$ is accompanied by abnormalities in brain insulin signaling[61] which could affect appetite and food intake. It is not clear if weight loss is a consequence of $\mathrm{AD}$, a parallel process, or if it is related to potential causes of $\mathrm{AD}$, such as insulin resistance[62]. The role of weight loss and nutritional supplementation in the progression of $\mathrm{AD}$ is beyond the scope of this review and can be found elsewhere[63-66].

\section{Hyperinsulinemia}

Several cross-sectional studies show an association between hyperinsulinemia and an increased risk of AD [67-69]. Two longitudinal studies, one in elderly Japanese Americans in Hawaii [70], and another in elderly Black, Caribbean Hispanic, and Non-Hispanic Whites in New York City [8] found that the risk of incident $\mathrm{AD}$ was higher in persons with hyperinsulinemia. These studies also found that the risk of $\mathrm{AD}$ related to hyperinsulinemia was higher among persons with the APOE- $\varepsilon 4$. The Nurses' health study found that higher C-peptide levels, a measure of insulin secretion [71], and fasting insulin levels are related to cognitive decline in women [72-74] There is a paucity of prospective epidemiologic studies exploring the relation between markers of hyperinsulinemia and $\mathrm{AD}$ and more are needed.

\section{Type 2 diabetes}

T2D has been related to a two-fold higher risk of developing MCI among postmenopausal women [75]. A multiethnic study in elderly from New York city found that T2D was related to a higher risk of cognitive impairment-no dementia with stroke although the effect on cognitive impairment-no dementia without stroke was not evident after adjusting for demographic variables and the presence of Apo E- $\varepsilon 4$ allele [76]. An Italian study showed a non-statistically significant increase of MCI with T2D in an elderly population[77], while a Canadian study found that T2D was related only to vascular cognitive impairment-no dementia [78]. A study in New York City found that T2D was related to a higher risk of both amnestic and non-amnestic $\mathrm{MCI}$, underlining the importance of T2D for both $\mathrm{AD}$ related and vascular cognitive impairment [79]. A recent study in Olmstead county, Minnesota found that presence of T2D was not related to MCI risk, but longer T2D duration and treatment with insulin, a surrogate marker of T2D duration, were related to higher MCI risk[80].

T2D has been found consistently to be related to vascular dementia (VD) but its relation to AD is less clear. A study of Japanese subjects aged 65 years and older found that T2D was related to a higher risk of both $\mathrm{AD}$ and $\mathrm{VD}$ [81]. A longitudinal study from the Netherlands in over 5,000 subjects aged 55 years and older without dementia at baseline found a higher risk of AD in persons with T2D [82]. This association was stronger in subjects with T2D who reported insulin treatment. Another European study found that the risk of all cause-dementia was 
increased by T2D but this relation was weaker with AD [83]. A study from Rochester, Minnesota found a doubling of AD risk in relation to T2D [84], similar to the study from the Netherlands. A study of catholic nuns, priests, and brothers 55 years and older found that T2D was associated with a higher risk of AD [85]. The Honolulu Asia Aging Study also found that $\mathrm{T} 2 \mathrm{D}$ in old age was related to a higher risk of $\mathrm{AD}$ and $\mathrm{AD}$ pathology on autopsy, particularly in subjects with the APOE- $\varepsilon 4$ allele [7]. A study from Canada found that T2D had a weak nonstatistically significant relation to AD, but was related to VD. A Swedish study found a similar non-significant relation to $\mathrm{AD}$, and a significant relation to a higher risk of $\mathrm{VD}$ [86]. A prospective study in over 1,000 subjects from New York City who were mostly African American and Caribbean-Hispanic, with a mean age of 75 years, and without dementia at baseline found a higher risk of $\mathrm{AD}$ in relation to $\mathrm{T} 2 \mathrm{D}$ which was not statistically significant after adjustment for other variables, but T2D was significantly related to higher risk of a composite outcome of $\mathrm{AD}$ and cognitive impairment-no dementia [76]. The risk of $\mathrm{AD}$ was also increased in those treated with insulin, indicating a higher risk of $\mathrm{AD}$ in subjects with long-standing T2D. This study also found a stronger association between T2D and VD. A recent reanalysis of these data with longer follow-up showed that the risk of AD associated with T2D was stronger than previously reported independent of other vascular conditions (hypertension, heart disease, stroke) and not explained by misclassification of VD cases as AD [87]. A study in Sweden found that T2D increased the risk of VD but not of AD [86], and that this risk was higher in the presence of hypertension and heart disease. The same study recently reported that borderline $\mathrm{T} 2 \mathrm{D}$ was associated with a higher risk of $\mathrm{AD}$ in persons without the APOE- $\varepsilon 4$ allele[88].

Few studies have examined if T2D in middle age leads to the development of dementia in older age. One study in the United States [89] and another in Israel [90] found that T2D at midlife increased the risk of dementia in the elderly. A study in Japanese-Americans found no association between T2D in middle age and dementia [91].

The diagnosis of T2D is somewhat arbitrary and many cases go undetected. Few studies have examined the relation between continuous measures of glycemia and dementia. One study in postmenopausal women found that the risk of MCI and dementia increased with each $1 \%$ elevation in glycosilated hemoglobin, a stable measure of glucose levels, even in women without T2D [92]. Glycosilated hemoglobin in persons without T2D correlates with both glucose intolerance and insulin resistance, and this study underscores the continuous nature of the relation between these constructs and higher dementia risk.

\section{Metabolic syndrome}

There is limited evidence on the association between the metabolic syndrome and dementia in the elderly. One study in 2,632 black and white elders found that the metabolic syndrome was associated with a higher risk of cognitive decline, particularly among those with high inflammatory markers [41]. A cross-sectional study in Europeans found that AD prevalence was higher in persons with the metabolic syndrome [93]. In Northern New York City the metabolic syndrome was not related to AD risk, while T2D and hyperinsulinemia were [94]. The discrepancy between these studies could be due to the fact that the study in New York City was conducted in an older population, ethnically diverse, and with a high prevalence of vascular risk factors [87]. In Japanese Americans the metabolic syndrome in middle age was associated with $\mathrm{VD}$, but not $\mathrm{AD}[95]$. 


\section{Potential mechanisms linking adiposity, hyperinsulinemia and diabetes to Alzheimer's disease}

This section includes a brief description of mechanisms. It is important to point out that these mechanisms overlap and may be highly correlated. Figure 1 attempts to depict the sequence and interrelation of these mechanisms.

\section{Hyperinsulinemia}

As described previously, one of the main consequences of adiposity is insulin resistance and hyperinsulinemia [17]. The role of insulin in AD is attracting increasing attention [96]. Insulin can cross the blood brain barrier from the periphery to the central nervous system and compete with $A \beta$ for insulin degrading enzyme (IDE) in the brain, including in the hippocampus [97]. Insulin is also produced in the brain, and may have, alternatively, a beneficial effect on amyloid clearance [98]. Peripheral hyperinsulinemia may also inhibit brain insulin production which, in turn results in impaired amyloid clearance and a higher risk of AD [98]. Thus, it is possible that decreasing peripheral hyperinsulinemia and increasing brain insulin levels have the same beneficial effect on AD. A study found that rosiglitazone, a drug used in T2D treatment which decreases insulin resistance and decreases peripheral insulin levels may also be beneficial in $\mathrm{AD}$ [99]. Interestingly, intranasal insulin, delivered with direct access to the brain without accessing the periphery has a similar effect [98]. Manipulation of blood insulin levels in humans has been demonstrated to affect cognition and levels of amyloid $\beta$ in the cerebrospinal fluid $[100,101]$, supporting the potential direct role of insulin in AD.

\section{Advanced glycosylation end products (AGEs)}

AGEs result from impaired glucose tolerance and diabetes, which often accompany or follow high adiposity and are responsible for their related end organ damage [102]. AGEs can be identified immunohistochemically in senile plaques and neurofibrillary tangles, the pathologic hallmarks of $\mathrm{AD}$ [5]. Glycation of amyloid $\beta$ enhances its aggregation in vitro. Furthermore, receptors for AGEs have been found to be specific cell surface receptors for amyloid $\beta$, thus potentially facilitating neuronal damage [102].

\section{Adipokines and cytokines}

Adipose tissue has been traditionally viewed as a passive energy-dense depot. As a dietary component, fat contains the most energy per gram than any other dietary component. Recent evidence shows that adipose tissue is active and produces a series of substances that are important in metabolism (adipokines), and inflammation (cytokines). Examples of adipokines include adiponectin [103], leptin[104], and resistin [104], and of inflammatory cytokines include Tumor Necrosis Factor- $\alpha$, and Interleukin-6 [104]. All are correlated with insulin resistance and hyperinsulinemia. It is unclear at this point whether adipokines and cytokines produced by adipose tissue are directly related to $\mathrm{AD}$ or whether they are only markers of insulin resistance and hyperinsulinemia. Systemic inflammation may be important and AD $[41,105,106]$. However, it is not clear whether systemic inflammation could just be a marker of cardiovascular disease[107], or be a marker and cause of insulin resistance [108]. However, some evidence links adipokines directly to cognition. Blood leptin levels are directly correlated with adiposity,[109,110] and the CA1 nucleus of the hippocampus, which may be affected in $\mathrm{AD}$, is directly affected by adipose-derived hormones such as leptin. Leptin has been shown to have numerous effects on brain development [111] and potentially on brain health in cognition and aging, affecting the function of the hypothalamus, and learning and memory processes controlled by the hippocampus.[112] In adults with a recessive mutation in the $o b$ gene (homologous to $o b / o b$ mice), leptin replacement is trophic for the brain, and increases gray matter tissue in the anterior cingulate gyrus, the inferior parietal lobe, and cerebellum. 
[113] Presence of the leptin receptor in the hippocampus, hypothalamus, amygdala, cerebellum, and brain stem indicates potentially linked regulatory mechanisms.[111,112] Recent experimental data show that leptin and adiponectin interact directly with hypothalamic nuclei and regulate energy expenditure and hyperphagic responses.[114,115] Leptin, may even shape the hypothalamus in the earliest stages of development and enhance cognition.[111] Direct leptin administration has been shown to improve memory processing in mice and enhance NMDA receptors.[111] However, other roles of leptin and related adipose-derived factors in the Alzheimer brain are not clear.[116-118] Fasting plasma leptin has been inversely correlated with grey matter volume in areas of the brain in which obese have reduced grey matter in comparison with lean individuals.[119]

\section{Microvascular and macrovascular complications of type 2 diabetes}

Microvascular complications of T2D include renal and retinal disease. It is thought that white matter disease in the brain visualized as white matter hyperintensities or leukoaraiosis are due to microvascular disease[120] and these have been found to be common in persons with T2D [121]. Brain infarcts are macrovascular complications of T2D. The role of white matter hyperintensities and infarcts in the amyloid cascade that leads to AD is not clear. However, it is thought that cerebrovascular disease at least lowers the threshold for the clinical manifestation of $\mathrm{AD}[122]$

\section{Other vascular risk factors}

Hypertension and dyslipidemia accompany adiposity and T2D and cause cerebrovascular disease[123]. As previously mentioned, Cerebrovascular disease is related to a higher risk of $\mathrm{AD}[124,125]$. An autopsy study showed that large vessel cerebrovascular disease, but not small vessel disease or infarcts, were related to a higher frequency of senile plaques [126], the pathologic hallmark of $\mathrm{AD}[5]$.

\section{The renin-angiotensin system (RAS)}

The classical function of the RAS is blood pressure regulation, but RAS may also provide a link between obesity, hypertension, and vascular syndromes, such as T2D, and health of the brain. $[127,128]$ Human brain and adipose tissue express a full RAS. Adipose RAS is involved in adipocyte growth, differentiation, and metabolism.[129] The RAS is activated in response to low levels of blood pressure, when angiotensin is converted by renin to angiotensin I, which is subsequently converted to angiotensin II by ACE. Angiotensin II interacts with angiotensin receptors 1 and 2, to mediate major cardiovascular effects of the RAS, such as increasing blood pressure.[127] In the brain, angiotensin II continues conversion to angiotensin IV, which, acting through angiotensin receptor 4 (also known as insulin-regulated aminopeptidase, IRAP),[130,131] enhances learning and memory in animal models.[131]

\section{Implications for the prevention and treatment of Alzheimer's disease}

There is very strong evidence that adiposity, hyperinsulinemia, and T2D are related to AD. However, this evidence comes short of being considered as proof of causation until we understand the mechanisms. If the relation between these conditions and $\mathrm{AD}$ were to be causal, the public health implications are enormous. As explained before, $2 / 3$ of the adult population of the United States are overweight or obese, and the short term trend is for this to worsen. These trends are also being observed worldwide. Epidemiologic studies suggest that adiposity in middle age is important as a predictor of AD risk. With increasing life expectancy we are likely to increasingly see the cognitive consequences of increased adiposity, hyperinsulinemia, and T2D in old age. We estimated that in New York City the presence of T2D or hyperinsulinemia in elderly people could account for 39\% of cases of AD [8]. However, the other implication is that a large proportion of cases of $\mathrm{AD}$ could be preventable or treatable. 
The Finnish Diabetes Prevention Study (FDPS) [132] demonstrated that T2D can be prevented with lifestyle interventions. The Diabetes Prevention Program (DPP) in the United States demonstrated that T2D can be prevented through lifestyle interventions or metformin[133] and this effect was largely mediated by improvements in insulin sensitivity and reductions in insulin levels[134]. Cognition ancillary studies are planned for both the FDPS and DPP. These cognition ancillary studies will be unique opportunities to answer whether the prevention of T2D through improvement in adiposity and insulin sensitivity are related to improvements in the risk of cognitive impairment. Rosiglitazone, and insulin sensitizer used in the treatment of T2D but also shown to be effective in prevention[135] have shown preliminary promise [136] in the treatment of AD, particularly in persons without the APOE- $\varepsilon 4$ allele[99]. Phase III trials of rosiglitazone are under way although concerns about its safety may make limit this drug's usefulness $[137,138]$. The potential mechanisms linking the continuum of adiposity, hyperinsulinemia, and T2D are multiple, overlapping, and highly correlated. Thus, it may be difficult to elucidate that a single mechanism is the culprit. Importantly, the potential therapeutic interventions mentioned above impact virtually all potential mechanisms. That is, weight loss through lifestyle interventions or medications alters adipokine activity, improves hyperinsulinemia, inflammation, glucose tolerance, blood pressure, lipids, and the risk of cerebrovascular disease. One of the pitfalls of the clinical diagnosis of AD is that it may detect a heterogenous disease with overlapping vascular and amyloid pathologies in a continuum. This may explain the observation of relations of adiposity, hyperinsulinemia, T2D with AD. It is possible that these relations are explained mostly by cases of dementia with cerebrovascular disease misclassified as $\mathrm{AD}$, or that are cases of mixed dementia. However, the possibility of misclassification does not reduce the potential public health importance of these observations and the potential for prevention and treatment.

Another important question is whether intense treatment can decrease the risk of cognitive impairment and $\mathrm{AD}$ in persons with T2D. Moreover, it is important to answer whether treatment of T2D with drugs that increase insulin levels vs. insulin sensitizers affect cognitive impairment. Some of these questions will be answered by a cognition ancillary study in the Action to Control Cardiovascular Risk in Diabetes (ACCORD) clinical trial [139]. Elucidating the mechanisms linking adiposity, hyperinsulinemia and T2D to AD will help identify specific targets for treatment and more research is needed in this regard.

\section{Acknowledgments}

Dr. Luchsinger's work in this review was supported by grants from the National Institute on Aging (AG07232), by the Alzheimer's Association (IIRG-05-15053), the American Diabetes Association (7-08-CR-41) and by the Florence and Herbert Irving Clinical Research Scholar's Award.

Dr. Gustafson's work in this review was supported by grants from the Swedish Research Council, the Swedish Brain Power Project, the National Institutes of Health/National Institutes on Aging 1R03AG026098, and the Alzheimer's Association (ZEN-01-3151).

\section{References}

1. Ritchie K, Lovestone S. The dementias. Lancet 2002;360:1759-1766. [PubMed: 12480441]

2. Brookmeyer R, Gray S, Kawas C. Projections of Alzheimer's disease in the United States and the public health impact of delaying disease onset. Am J Public Health 1998;88:1337-1342. [PubMed: 9736873]

3. Evans DA, Funkenstein HH, Albert MS, Scherr PA, Cook NR, Chown MJ, Hebert LE, Hennekens $\mathrm{CH}$, Taylor JO. Prevalence of Alzheimer's disease in a community population of older persons. Higher than previously reported. JAMA 1989;262:2551-2556. [PubMed: 2810583]

4. Selkoe DJ. Alzheimer's disease: genotypes, phenotypes, and treatments. Science 1997;275:630-631. [PubMed: 9019820]

5. Cummings JL. Alzheimer's Disease. N Engl J Med 2004;351:56-67. [PubMed: 15229308] 
6. Haan MN, Shemanski L, Jagust WJ, Manolio TA, Kuller L. The role of APOE epsilon4 in modulating effects of other risk factors for cognitive decline in elderly persons. JAMA 1999;282:40-46. [PubMed: 10404910]

7. Peila R, Rodriguez BL, Launer LJ, Honolulu-Asia Aging S. Type 2 diabetes, APOE gene, and the risk for dementia and related pathologies: The Honolulu-Asia Aging Study. Diabetes 2002;51:1256-1262. [PubMed: 11916953]

8. Luchsinger JA, Tang MX, Shea S, Mayeux R. Hyperinsulinemia and risk of Alzheimer disease. Neurology 2004;63:1187-1192. [PubMed: 15477536]

9. Sano M. Noncholinergic treatment options for Alzheimer's disease. J Clin Psychiatry 2003;64:23-28. [PubMed: 12934971]

10. Selkoe DJ. The origins of Alzheimer disease: a is for amyloid. JAMA 2000;283:1615-1617. [PubMed: 10735401]

11. Luis CA, Loewenstein DA, Acevedo A, Barker WW, Duara R. Mild cognitive impairment: directions for future research. Neurology 2003;61:438-444. [PubMed: 12939414]

12. Petersen RC, Smith GE, Waring SC, Ivnik RJ, Tangalos EG, Kokmen E. Mild cognitive impairment: clinical characterization and outcome. Arch Neurol 1999;56:303-308. [PubMed: 10190820]

13. Petersen RC, Thomas RG, Grundman M, Bennett D, Doody R, Ferris S, Galasko D, Jin S, Kaye J, Levey A, Pfeiffer E, Sano M, van Dyck CH, Thal LJ, the Alzheimer's Disease Cooperative Study Group. Vitamin E and Donepezil for the Treatment of Mild Cognitive Impairment. N Engl J Med. 2005NEJMoa050151

14. Busse A, Bischkopf J, Riedel-Heller SG, Angermeyer MC. Mild cognitive impairment: prevalence and incidence according to different diagnostic criteria. Results of the Leipzig Longitudinal Study of the Aged (LEILA75+). Br J Psychiatry 2003;182:449-454. [PubMed: 12724250]

15. Yesavage JA, O'Hara R, Kraemer H, Noda A, Taylor JL, Ferris S, Gely-Nargeot MC, Rosen A, Friedman L, Sheikh J, Derouesne C. Modeling the prevalence and incidence of Alzheimer's disease and mild cognitive impairment. J Psychiatr Res 2002;36:281-286. [PubMed: 12127595]

16. Hill JO, Bessesen D. What to do about the metabolic syndrome? Arch Intern Med 2003;163:395397. [PubMed: 12588197]

17. Reaven, GM.; Laws, A. Insulin resistance: the metabolic syndrome X. Humana Press; Totowa, New Jersey: 1999.

18. Poirier P, Giles TD, Bray GA, Hong Y, Stern JS, Pi-Sunyer FX, Eckel RH. Obesity and Cardiovascular Disease: Pathophysiology, Evaluation, and Effect of Weight Loss: An Update of the 1997 American Heart Association Scientific Statement on Obesity and Heart Disease From the Obesity Committee of the Council on Nutrition, Physical Activity, and Metabolism. Circulation 2006;113:898-918. [PubMed: 16380542]

19. Pi-Sunyer FX. The Obesity Epidemic: Pathophysiology and Consequences of Obesity. Obes Res 2002;10:97S-104. [PubMed: 12490658]

20. Clinical Guidelines on the Identification, Evaluation, and Treatment of Overweight and Obesity in Adults--The Evidence Report. National Institutes of Health [published erratum appears in Obes Res 1998 Nov;6(6):464]. Obesity Res 1998;6:51S-209.

21. Mueller WH, Wear ML, Hanis CL, Emerson JB, Barton SA, Hewett-Emmett D, Schull WJ. Which measure of body fat distribution is best for epidemiologic research? Am J Epidemiol 1991;133:858869. [PubMed: 2028976]

22. Baumgartner RN, Heymsfield SB, Roche AF. Human body composition and the epidemiology of chronic disease. Obes Res 1995;3:73-95. [PubMed: 7712363]

23. Wahrenberg H, Hertel K, Leijonhufvud BM, Persson LG, Toft E, Arner P. Use of waist circumference to predict insulin resistance: retrospective study. BMJ 2005;330:1363-1364. [PubMed: 15833749]

24. Janssen I, Katzmarzyk PT, Ross R. Waist circumference and not body mass index explains obesityrelated health risk. Am J Clin Nutr 2004;79:379-384. [PubMed: 14985210]

25. Flegal KM, Carroll MD, O CL, J CL. Prevalence and trends in obesity among US adults, 1999-2000. JAMA 2002;288:1723-1727. [PubMed: 12365955]

26. Ford ES, Mokdad AH, Giles WH. Trends in Waist Circumference among U.S. Adults. Obes Res 2003;11:1223-1231. [PubMed: 14569048] 
27. Hedley AA, Ogden CL, Johnson CL, Carroll MD, Curtin LR, Flegal KM. Prevalence of Overweight and Obesity Among US Children, Adolescents, and Adults, 1999-2002. JAMA 2004;291:28472850. [PubMed: 15199035]

28. Lillioja S, Mott DM, Spraul M, Ferraro R, Foley JE, Ravussin E, Knowler WC, Bennett PH, Bogardus C. Insulin resistance and insulin secretory dysfunction as precursors of non-insulin-dependent diabetes mellitus. Prospective studies of Pima Indians. N Engl J Med 1993;329:1988-1992. [PubMed: 8247074]

29. Haffner SM, Stern MP, Mitchell BD, Hazuda HP, Patterson JK. Incidence of type II diabetes in Mexican Americans predicted by fasting insulin and glucose levels, obesity, and body-fat distribution. Diabetes 1990;39:283-288. [PubMed: 2407581]

30. Lundgren H, Bengtsson C, Blohme G, Lapidus L, Waldenstrom J. Fasting serum insulin concentration and early insulin response as risk determinants for developing diabetes. Diabetic Medicine 1990;7:407-413. [PubMed: 2142037]

31. Charles MA, Fontbonne A, Thibult N, Warnet JM, Rosselin GE, Eschwege E. Risk factors for NIDDM in white population. Paris prospective study. Diabetes 1991;40:796-799. [PubMed: 2060716]

32. Laakso M. How good a marker is insulin level for insulin resistance? Am J Epidemiol 1993;137:959965. [PubMed: 8317453]

33. Haffner SM, Miettinen H, Stern MP. The homeostasis model in the San Antonio Heart Study. Diabetes Care 1997;20:1087-1092. [PubMed: 9203442]

34. DeFronzo RA. Pharmacologic therapy for type 2 diabetes mellitus. Ann Intern Med 2000;133:7374. [PubMed: 10877745]

35. Clark MJ Jr, Sterrett JJ, Carson DS. Diabetes Guidelines: A Summary and Comparison of the Recommendations of the American Diabetes Association, Veterans Health Administration, and American Association of Clinical Endocrinologists. Clinical Therapeutics 2000;22:899-910. [PubMed: 10972628]

36. Luchsinger, JA. Diabetes. In: Aguirre-Molina, M.; Molina, CW.; Zambrana, RE., editors. Health issues in the Latino community. Jossey-Bass; San Francisco: 2001. p. 277-300.

37. Festa A, Williams K, D'Agostino R Jr, Wagenknecht LE, Haffner SM. The Natural Course of \{beta $\}$ Cell Function in Nondiabetic and Diabetic Individuals: The Insulin Resistance Atherosclerosis Study. Diabetes 2006;55:1114-1120. [PubMed: 16567536]

38. Reaven G. Insulin Resistance, Type 2 Diabetes Mellitus, and Cardiovascular Disease: The End of the Beginning. Circulation 2005;112:3030-3032. [PubMed: 16286599]

39. Accili D. Lilly Lecture 2003: The Struggle for Mastery in Insulin Action: From Triumvirate to Republic. Diabetes 2004;53:1633-1642. [PubMed: 15220184]

40. Kraja AT, Hunt SC, Pankow JS, Myers RH, Heiss G, Lewis CE, Rao D, Province MA. An evaluation of the metabolic syndrome in the HyperGEN study. Nutr Metab (Lond) 2005;2:2. [PubMed: 15656912]

41. Yaffe K, Kanaya A, Lindquist K, Simonsick EM, Harris T, Shorr RI, Tylavsky FA, Newman AB. The Metabolic Syndrome, Inflammation, and Risk of Cognitive Decline. JAMA 2004;292:22372242. [PubMed: 15536110]

42. Grundy SM, Cleeman JI, Daniels SR, Donato KA, Eckel RH, Franklin BA, Gordon DJ, Krauss RM, Savage PJ, Smith SC Jr, Spertus JA, Costa F. Diagnosis and Management of the Metabolic Syndrome: An American Heart Association/National Heart, Lung, and Blood Institute Scientific Statement. Circulation 2005;112:2735-2752. [PubMed: 16157765]

43. Luchsinger JA. A work in progress: the metabolic syndrome. Sci Aging Knowledge Environ 2006;2006:pe19. [PubMed: 16807483]

44. Kivipelto M, Ngandu T, Fratiglioni L, Viitanen M, Kareholt I, Winblad B, Helkala EL, Tuomilehto J, Soininen H, Nissinen A. Obesity and vascular risk factors at midlife and the risk of dementia and Alzheimer disease. Arch Neurol 2005;62:1556-1560. [PubMed: 16216938]

45. Whitmer RA, Gunderson EP, Barrett-Connor E, Quesenberry CP Jr, Yaffe K. Obesity in middle age and future risk of dementia: a 27 year longitudinal population based study. BMJ. 2005bmj. 38446.466238.E466230

46. Whitmer RA, Gustafson DR, Barrett-Connor E, Haan MN, Gunderson EP, Yaffe K. Central obesity and increased risk of dementia more than three decades later. Neurology. 2008 
47. Gustafson D, Rothenberg E, Blennow K, Steen B, Skoog I. An 18-Year Follow-up of Overweight and Risk of Alzheimer Disease. Arch Intern Med 2003;163:1524-1528. [PubMed: 12860573]

48. Stewart R, Masaki K, Xue QL, Peila R, Petrovitch H, White LR, Launer LJ. A 32-Year Prospective Study of Change in Body Weight and Incident Dementia: The Honolulu-Asia Aging Study. Arch Neurol 2005;62:55-60. [PubMed: 15642850]

49. Atti AR, Palmer K, Volpato S, Winblad B, De Ronchi D, Fratiglioni L. Late-life body mass index and dementia incidence: nine-year follow-up data from the Kungsholmen Project. J Am Geriatr Soc 2008;56:111-116. [PubMed: 18028342]

50. Nourhashemi F, Deschamps V, Larrieu S, Letenneur L, Dartigues JF, Barberger-Gateau P, Quid PsPA. Body mass index and incidence of dementia: the PAQUID study. Neurology 2003;60:117119. [PubMed: 12525731]

51. Buchman AS, Wilson RS, Bienias JL, Shah RC, Evans DA, Bennett DA. Change in body mass index and risk of incident Alzheimer disease. Neurology 2005;65:892-897. [PubMed: 16186530]

52. Knopman DS, Edland SD, Cha RH, Petersen RC, Rocca WA. Incident dementia in women is preceded by weight loss by at least a decade. Neurology 2007;69:739-746. [PubMed: 17709705]

53. White H, Pieper C, Schmader K, Fillenbaum G. Weight change in Alzheimer's disease. J Am Geriatr Soc 1996;44:265-272. [PubMed: 8600194]

54. Gustafson D. A life course of adiposity and dementia. Eur J Pharmacol 2008;585:163-175. [PubMed: 18423446]

55. Luchsinger JA, Patel B, Tang MX, Schupf N, Mayeux R. Measures of adiposity and dementia risk in elderly persons. Arch Neurol 2007;64:392-398. [PubMed: 17353383]

56. Stevens J, Cai J, Pamuk ER, Williamson DF, Thun MJ, Wood JL. The effect of age on the association between body-mass index and mortality. N Engl J Med 1998:1-7. [PubMed: 9414324]

57. Stevens J. Impact of age on associations between weight and mortality. Nutr Rev 2000;58:129-137. [PubMed: 10860392]

58. Fitzpatrick AL, K LH, Lopez OL, Diehr POM E, Longstreth WT, Luchsinger JA. Obesity: Risk of Dementia in the Cardiovascular Health Cognition Study. Arch Neurol. in press

59. Tabert MH, Liu X, Doty RL, Serby M, Zamora D, Pelton GH, Marder K, Albers MW, Stern Y, Devanand DP. A 10-item smell identification scale related to risk for Alzheimer's disease. Ann Neurol 2005;58:155-160. [PubMed: 15984022]

60. Devanand DP, Michaels-Marston KS, Liu X, Pelton GH, Padilla M, Marder K, Bell K, Stern Y, Mayeux R. Olfactory deficits in patients with mild cognitive impairment predict Alzheimer's disease at follow-up. Am J Psychiatry 2000;157:1399-1405. [PubMed: 10964854]

61. Steen E, Terry BM, Rivera EJ, Cannon JL, Neely TR, Tavares R, Xu XJ, Wands JR, de la Monte SM. Impaired insulin and insulin-like growth factor expression and signaling mechanisms in Alzheimer's disease--is this type 3 diabetes? J Alzheimers Dis 2005;7:63-80. [PubMed: 15750215]

62. Wedick NM, Mayer-Davis EJ, Wingard DL, Addy CL, Barrett-Connor E. Insulin Resistance Precedes Weight Loss in Adults without Diabetes : The Rancho Bernardo Study. Am J Epidemiol 2001;153:1199-1205. [PubMed: 11415955]

63. Reynish W, Andrieu S, Nourhashemi F, Vellas B. Nutritional factors and Alzheimer's disease. J Gerontol A-Biol Sci Med Sci 2001;56:M675-680. [PubMed: 11682574]

64. Reyes-Ortega G, Guyonnet S, Ousset PJ, Nourhashemi F, Vellas B, Albarede JL, De Glizezinski I, Riviere D, Fitten LJ. Weight loss in Alzheimer's disease and resting energy expenditure (REE), a preliminary report. J Am Geriatr Soc 1997;45:1414-1415. [PubMed: 9361678]

65. Guyonnet S, Nourhashemi F, Ousset PJ, Micas M, Ghisolfi A, Vellas B, Albarede JL. Factors associated with weight loss in Alzheimer's disease. J Nutr Health Aging 1998;2:107-109. [PubMed: 10993577]

66. Andrieu S, Reynish W, Nourhashemi F, Ousset PJ, Grandjean H, Grand A, Albarede JL, Vellas B. Nutritional risk factors for institutional placement in Alzheimer's disease after one year follow-up. $\mathrm{J}$ Nutr Health Aging 2001;5:113-117. [PubMed: 11426292]

67. Razay G, Wilcock GK. Hyperinsulinaemia and Alzheimer's disease. Age Ageing 1994;23:396-399. [PubMed: 7825486]

68. Kuusisto J, Koivisto K, Mykkanen L, Helkala EL, Vanhanen M, Hanninen T, Kervinen K, Kesaniemi YA, Riekkinen PJ, Laakso M. Association between features of the insulin resistance syndrome and 
Alzheimer's disease independently of apolipoprotein E4 phenotype: cross sectional population based study. BMJ 1997;315:1045-1049. [PubMed: 9366728]

69. Stolk RP, Breteler MM, Ott A, Pols HA, Lamberts SW, Grobbee DE, Hofman A. Insulin and cognitive function in an elderly population. The Rotterdam Study. Diabetes Care 1997;20:792-795. [PubMed: 9135944]

70. Peila R, Rodriguez BL, White LR, Launer LJ. Fasting insulin and incident dementia in an elderly population of Japanese-American men. Neurology 2004;63:228-233. [PubMed: 15277613]

71. Harris MI, Cowie CC, Gu K, Francis ME, Flegal K, Eberhardt MS. Higher fasting insulin but lower fasting C-peptide levels in African Americans in the US population. Diabetes/Metabolism Research Reviews 2002;18:149-155.

72. Okereke OI, Pollak MN, Hu FB, Hankinson SE, Selkoe DJ, Grodstein F. Plasma C-peptide levels and rates of cognitive decline in older, community-dwelling women without diabetes. Psychoneuroendocrinology 2008;33:455-461. [PubMed: 18261857]

73. van Oijen M, Okereke OI, Kang JH, Pollak MN, Hu FB, Hankinson SE, Grodstein F. Fasting insulin levels and cognitive decline in older women without diabetes. Neuroepidemiology 2008;30:174179. [PubMed: 18421217]

74. Okereke O, Hankinson SE, Hu FB, Grodstein F. Plasma C Peptide Level and Cognitive Function Among Older Women Without Diabetes Mellitus. Arch Intern Med 2005;165:1651-1656. [PubMed: 16043685]

75. Yaffe K, Blackwell T, Kanaya AM, Davidowitz N, Barrett-Connor E, Krueger K. Diabetes, impaired fasting glucose, and development of cognitive impairment in older women. Neurology 2004;63:658663. [PubMed: 15326238]

76. Luchsinger JA, Tang MX, Stern Y, Shea S, Mayeux R. Diabetes mellitus and risk of Alzheimer's disease and dementia with stroke in a multiethnic cohort. Am J Epidemiol 2001;154:635-641. [PubMed: 11581097]

77. Solfrizzi V, Panza F, Colacicco AM, D'Introno A, Capurso C, Torres F, Grigoletto F, Maggi S, Del Parigi A, Reiman EM, Caselli RJ, Scafato E, Farchi G, Capurso A. Vascular risk factors, incidence of MCI, and rates of progression to dementia. Neurology 2004;63:1882-1891. [PubMed: 15557506] for the Italian Longitudinal Study on Aging Working Group

78. MacKnight C, Rockwood K, Awalt E, McDowell I. Diabetes mellitus and the risk of dementia, Alzheimer's disease and vascular cognitive impairment in the Canadian Study of Health and Aging. Dement Geriatr Cogn Disord 2002;14:77-83. [PubMed: 12145454]

79. Luchsinger JA, Reitz C, Patel B, Tang MX, Manly JJ, Mayeux R. Relation of Diabetes to Mild Cognitive Impairment. Arch Neurol 2007;64:570-575. [PubMed: 17420320]

80. Roberts RO, Geda YE, Knopman DS, Christianson TJ, Pankratz VS, Boeve BF, Vella A, Rocca WA, Petersen RC. Association of duration and severity of diabetes mellitus with mild cognitive impairment. Arch Neurol 2008;65:1066-1073. [PubMed: 18695056]

81. Yoshitake T, Kiyohara Y, Kato I, Ohmura T, Iwamoto H, Nakayama K, Ohmori S, Nomiyama K, Kawano H, Ueda K, et al. Incidence and risk factors of vascular dementia and Alzheimer's disease in a defined elderly Japanese population: the Hisayama Study. Neurology 1995;45:1161-1168. [PubMed: 7783883]

82. Ott A, Stolk RP, van Harskamp F, Pols HA, Hofman A, Breteler MM. Diabetes mellitus and the risk of dementia: The Rotterdam Study. Neurology 1999;53:1937-1942. [PubMed: 10599761]

83. Brayne C, Gill C, Huppert FA, Barkley C, Gehlhaar E, Girling DM, O'Connor DW, Paykel ES. Vascular risks and incident dementia: results from a cohort study of the very old. Dement Geriatr Cogn Disord 1998;9:175-180. [PubMed: 9622006]

84. Leibson CL, Rocca WA, Hanson VA, Cha R, Kokmen E, O'Brien PC, Palumbo PJ. Risk of dementia among persons with diabetes mellitus: a population- based cohort study. Am J Epidemiol 1997;145:301-308. [PubMed: 9054233]

85. Arvanitakis Z, Wilson RS, Bienias JL, Evans DA, Bennett DA. Diabetes mellitus and risk of Alzheimer disease and decline in cognitive function. Arch Neurol 2004;61:661-666. [PubMed: $15148141]$ 
86. Xu WL, Qiu CX, Wahlin A, Winblad B, Fratiglioni L. Diabetes mellitus and risk of dementia in the Kungsholmen project: a 6-year follow-up study. Neurology 2004;63:1181-1186. [PubMed: 15477535]

87. Luchsinger JA, Reitz C, Honig LS, Tang MX, Shea S, Mayeux R. Aggregation of vascular risk factors and risk of incident Alzheimer disease. Neurology 2005;65:545-551. [PubMed: 16116114]

88. Xu W, Qiu C, Winblad B, Fratiglioni L. The Effect of Borderline Diabetes on the Risk of Dementia and Alzheimer's Disease. Diabetes 2007;56:211-216. [PubMed: 17192484]

89. Whitmer RA, Sidney S, Selby J, Johnston SC, Yaffe K. Midlife cardiovascular risk factors and risk of dementia in late life. Neurology 2005;64:277-281. [PubMed: 15668425]

90. Schnaider Beeri M, Goldbourt U, Silverman JM, Noy S, Schmeidler J, Ravona-Springer R, Sverdlick A, Davidson M. Diabetes mellitus in midlife and the risk of dementia three decades later. Neurology 2004;63:1902-1907. [PubMed: 15557509]

91. Curb JD, Rodriguez BL, Abbott RD, Petrovitch H, Ross GW, Masaki KH, Foley D, Blanchette PL, Harris T, Chen R, White LR. Longitudinal association of vascular and Alzheimer's dementias, diabetes, and glucose tolerance. Neurology 1999;52:971-975. [PubMed: 10102414]

92. Yaffe K, Blackwell T, Whitmer RA, Krueger K, Barrett Connor E. Glycosylated hemoglobin level and development of mild cognitive impairment or dementia in older women. J Nutr Health Aging 2006;10:293-295. [PubMed: 16886099]

93. Vanhanen M, Koivisto K, Moilanen L, Helkala EL, Hanninen T, Soininen H, Kervinen K, Kesaniemi YA, Laakso M, Kuusisto J. Association of metabolic syndrome with Alzheimer disease: A population-based study. Neurology 2006;67:843-847. [PubMed: 16966548]

94. Muller M, Tang MX, Schupf N, Manly JJ, Mayeux R, Luchsinger JA. Metabolic syndrome and dementia risk in a multiethnic elderly cohort. Dement Geriatr Cogn Disord 2007;24:185-192. [PubMed: 17641531]

95. Kalmijn S, Foley D, White L, Burchfiel CM, Curb JD, Petrovitch H, Ross GW, Havlik RJ, Launer LJ. Metabolic cardiovascular syndrome and risk of dementia in Japanese- American elderly men. The Honolulu-Asia aging study. Arterioscler Thromb Vasc Biol 2000;20:2255-2260. [PubMed: 11031212]

96. Strachan MWJ. Insulin and cognitive function. The Lancet 2003;362:1253.

97. Farris W, Mansourian S, Chang Y, Lindsley L, Eckman EA, Frosch MP, Eckman CB, Tanzi RE, Selkoe DJ, Guenette S. Insulin-degrading enzyme regulates the levels of insulin, amyloid betaprotein, and the beta-amyloid precursor protein intracellular domain in vivo. Proc Natl Acad Sci U S A 2003;100:4162-4167. [PubMed: 12634421]

98. Reger MA, Watson GS, Frey WH 2nd, Baker LD, Cholerton B, Keeling ML, Belongia DA, Fishel MA, Plymate SR, Schellenberg GD, Cherrier MM, Craft S. Effects of intranasal insulin on cognition in memory-impaired older adults: modulation by APOE genotype. Neurobiol Aging 2006;27:451458. [PubMed: 15964100]

99. Risner ME, Saunders AM, Altman JF, Ormandy GC, Craft S, Foley IM, Zvartau-Hind ME, Hosford DA, Roses AD. Efficacy of rosiglitazone in a genetically defined population with mild-to-moderate Alzheimer's disease. Pharmacogenomics J 2006;6:246-254. [PubMed: 16446752]

100. Watson GS, Bernhardt T, Reger MA, Cholerton BA, Baker LD, Peskind ER, Asthana S, Plymate SR, Frolich L, Craft S. Insulin effects on CSF norepinephrine and cognition in Alzheimer's disease. Neurobiol Aging 2006;27:38-41. [PubMed: 16298239]

101. Watson GS, Craft S. Modulation of memory by insulin and glucose: neuropsychological observations in Alzheimer's disease. Eur J Pharmacol 2004;490:97-113. [PubMed: 15094077]

102. Yamagishi S, Nakamura K, Inoue H, Kikuchi S, Takeuchi M. Serum or cerebrospinal fluid levels of glyceraldehyde-derived advanced glycation end products (AGEs) may be a promising biomarker for early detection of Alzheimer's disease. Med Hypotheses 2005;64:1205-1207. [PubMed: 15823718]

103. Trujillo ME, Scherer PE. Adiponectin - journey from an adipocyte secretory protein to biomarker of the metabolic syndrome. J Intern Med 2005;257:167-175. [PubMed: 15656875]

104. Yu YH, Ginsberg HN. Adipocyte signaling and lipid homeostasis: sequelae of insulin-resistant adipose tissue. Circ Res 2005;96:1042-1052. [PubMed: 15920027] 
105. Tan ZS, Beiser AS, Vasan RS, Roubenoff R, Dinarello CA, Harris TB, Benjamin EJ, Au R, Kiel DP, Wolf PA, Seshadri S. Inflammatory markers and the risk of Alzheimer disease: The Framingham Study. Neurology 2007;68:1902-1908. [PubMed: 17536046]

106. Yaffe K, Lindquist K, Penninx BW, Simonsick EM, Pahor M, Kritchevsky S, Launer L, Kuller L, Rubin S, Harris T. Inflammatory markers and cognition in well-functioning African-American and white elders. Neurology 2003;61:76-80. [PubMed: 12847160]

107. Ridker PM. High-sensitivity C-reactive protein, inflammation, and cardiovascular risk: from concept to clinical practice to clinical benefit. American Heart Journal 2004;148:S19-S26. [PubMed: 15211329]

108. The Diabetes Prevention Program Research Group. Intensive Lifestyle Intervention or Metformin on Inflammation and Coagulation in Participants With Impaired Glucose Tolerance. Diabetes 2005;54:1566-1572. [PubMed: 15855347]

109. Friedman J, Halaas L. Leptin and the regulation of body weight in mammals. Nature 1998;22:763770. [PubMed: 9796811]

110. Lissner L, Karlsson C, Lindroos AK, Sjostrom L, Carlsson B, Carlsson L, Bengtsson C. Birth weight, adulthood BMI, and subsequent weight gain in relation to leptin levels in Swedish women. Obes Res 1999;7:150-154. [PubMed: 10102251]

111. Harvey J, Shanley LJ, O'Malley D, Irving AJ. Leptin: a potential cognitive enhancer? Biochem Soc Trans 2005;33:1029-1032. [PubMed: 16246038]

112. Davidson TL, Kanoski SE, Walls EK, Jarrard LE. Memory inhibition and energy regulation. Physiol Behav 2005;86:731-746. [PubMed: 16263144]

113. Matochik JA, London ED, Yildiz BO, Ozata M, Caglayan S, DePaoli AM, Wong ML, Licinio J. Effect of leptin replacement on brain structure in genetically leptin-deficient adults. J Clin Endocrinol Metab 2005;90:2851-2854. [PubMed: 15713712]

114. Kishi T, Elmquist JK. Body weight is regulated by the brain: a link between feeding and emotion. Mol Psychiatry 2005;10:132-146. [PubMed: 15630408]

115. Qi Y, Takahashi N, Hileman SM, Patel HR, Berg AH, Pajvani UB, Scherer PE, Ahima RS. Adiponectin acts in the brain to decrease body weight. Nat Med 2004;10:524-529. [PubMed: 15077108]

116. Fewlass DC, Noboa K, Pi-Sunyer FX, Johnston JM, Yan SD, Tezapsidis N. Obesity-related leptin regulates Alzheimer's Abeta. FASEB J 2004;18:1870-1878. [PubMed: 15576490]

117. Olsson T, Nasman B, Rasmuson S, Ahren B. Dual relation between leptin and cortisol in humans is disturbed in Alzheimer's disease. Biol Psychiatry 1998;44:374-376. [PubMed: 9755363]

118. Power DA, Noel J, Collins R, O'Neill D. Circulating leptin levels and weight loss in Alzheimer's disease patients. Dement Geriatr Cogn Disord 2001;12:167-170. [PubMed: 11173891]

119. Pannacciulli N, Le DS, Chen K, Reiman EM, Krakoff J. Relationships between plasma leptin concentrations and human brain structure: a voxel-based morphometric study. Neurosci Lett 2007;412:248-253. [PubMed: 17123711]

120. Pantoni L. White matter ischemia: Time to begin integrating experimental and clinical data. Eur Neurol 2006;56:71-73. [PubMed: 16946617]

121. Manschot SM, Brands AMA, van der Grond J, Kessels RPC, Algra A, Kappelle LJ, Biessels GJ. Brain Magnetic Resonance Imaging Correlates of Impaired Cognition in Patients With Type 2 Diabetes. Diabetes 2006;55:1106-1113. [PubMed: 16567535] on behalf of the Utrecht Diabetic Encephalopathy Study G

122. Snowdon DA, Greiner LH, Mortimer JA, Riley KP, Greiner PA, Markesbery WR. Brain infarction and the clinical expression of Alzheimer disease. The Nun Study. JAMA 1997;277:813-817. [PubMed: 9052711]

123. Sacco RL, Benjamin EJ, Broderick JP, Dyken M, Easton JD, Feinberg WM, Goldstein LB, Gorelick PB, Howard G, Kittner SJ, Manolio TA, Whisnant JP, Wolf PA. American Heart Association Prevention Conference. IV. Prevention and Rehabilitation of Stroke. Risk factors. Stroke 1997;28:1507-1517. [PubMed: 9227708]

124. Vermeer SE, Prins ND, den Heijer T, Hofman A, Koudstaal PJ, Breteler MM. Silent brain infarcts and the risk of dementia and cognitive decline. N Engl J Med 2003;348:1215-1222. [PubMed: 12660385] 
125. Honig LS, Tang MX, Albert S, Costa R, Luchsinger J, Manly J, Stern Y, Mayeux R. Stroke and the risk of Alzheimer disease. Arch Neurol 2003;60:1707-1712. [PubMed: 14676044]

126. Honig LS, Kukull W, Mayeux R. Atherosclerosis and AD: Analysis of data from the US National Alzheimer's Coordinating Center. Neurology 2005;64:494-500. [PubMed: 15699381]

127. Goossens GH, Blaak EE, van Baak MA. Possible involvement of the adipose tissue renin-angiotensin system in the pathophysiology of obesity and obesity-related disorders. Obes Rev 2003;4:43-55. [PubMed: 12608526]

128. Katzov H, Bennet AM, Kehoe P, Wiman B, Gatz M, Blennow K, Lenhard B, Pedersen NL, deFaire U, Prince JA. A cladistic model of ACE sequence variation with implications for myocardial infarction, Alzheimer disease and obesity. Human Mol Genetics 2004;13:2647-2657.

129. Strazzullo P, Iacone R, Iacoviello L, Russo O, Barba G, Russo P, D'Orazio A, Barbato A, Cappuccio FP, Farinaro E, Siani A. Genetic variation in the renin-angiotensin system and abdominal adiposity in men: the Olivetti Prospective Heart Study. Ann Intern Med 2003;138:17-23. [PubMed: 12513040]

130. Savaskan E. The role of the brain renin-angiotensin system in neurodegenerative disorders. Curr Alzheimer Res 2005;2:29-35. [PubMed: 15977987]

131. Albiston AL, McDowall SG, Matsacos D, Sim P, Clune E, Mustafa T, Lee J, Mendelsohn FA, Simpson RJ, Connolly LM, Chai SY. Evidence that the angiotensin IV (AT(4)) receptor is the enzyme insulin-regulated aminopeptidase. J Biol Chem 2001;276:48623-48626. [PubMed: 11707427]

132. Tuomilehto J, Lindstrom J, Eriksson JG, Valle TT, Hamalainen H, Ilanne-Parikka P, KeinanenKiukaanniemi S, Laakso M, Louheranta A, Rastas M, Salminen V, Aunola S, Cepaitis Z, Moltchanov V, Hakumaki M, Mannelin M, Martikkala V, Sundvall J, Uusitupa M, the Finnish Diabetes Prevention Study Group. Prevention of Type 2 Diabetes Mellitus by Changes in Lifestyle among Subjects with Impaired Glucose Tolerance. N Engl J Med 2001;344:1343-1350. [PubMed: 11333990]

133. Diabetes Prevention Program Research Group. Reduction in the Incidence of Type 2 Diabetes with Lifestyle Intervention or Metformin. N Engl J Med 2002;346:393-403. [PubMed: 11832527]

134. The Diabetes Prevention Program Research Group. Role of Insulin Secretion and Sensitivity in the Evolution of Type 2 Diabetes in the Diabetes Prevention Program: Effects of Lifestyle Intervention and Metformin. Diabetes 2005;54:2404-2414. [PubMed: 16046308]

135. DREAM investigators. Effect of rosiglitazone on the frequency of diabetes in patients with impaired glucose tolerance or impaired fasting glucose: a randomised controlled trial. Lancet 2006;368:10961105. [PubMed: 16997664]

136. Watson GS, Cholerton BA, Reger MA, Baker LD, Plymate SR, Asthana S, Fishel MA, Kulstad JJ, Green PS, Cook DG, Kahn SE, Keeling ML, Craft S. Preserved Cognition in Patients With Early Alzheimer Disease and Amnestic Mild Cognitive Impairment During Treatment With Rosiglitazone: A Preliminary Study. Am J Geriatr Psychiatry 2005;13:950-958. [PubMed: 16286438]

137. Nathan DM, Berkwits M. Trials that matter: rosiglitazone, ramipril, and the prevention of type 2 diabetes. Ann Intern Med 2007;146:461-463. [PubMed: 17371892]

138. Nathan DM. Rosiglitazone and Cardiotoxicity -- Weighing the Evidence. N Engl J Med. 2007NEJMe078117

139. Williamson JD, Miller ME, Bryan RN, Lazar RM, Coker LH, Johnson J, Cukierman T, Horowitz KR, Murray A, Launer LJ. The Action to Control Cardiovascular Risk in Diabetes Memory in Diabetes Study (ACCORD-MIND): rationale, design, and methods. Am J Cardiol 2007;99:112i122 i. 


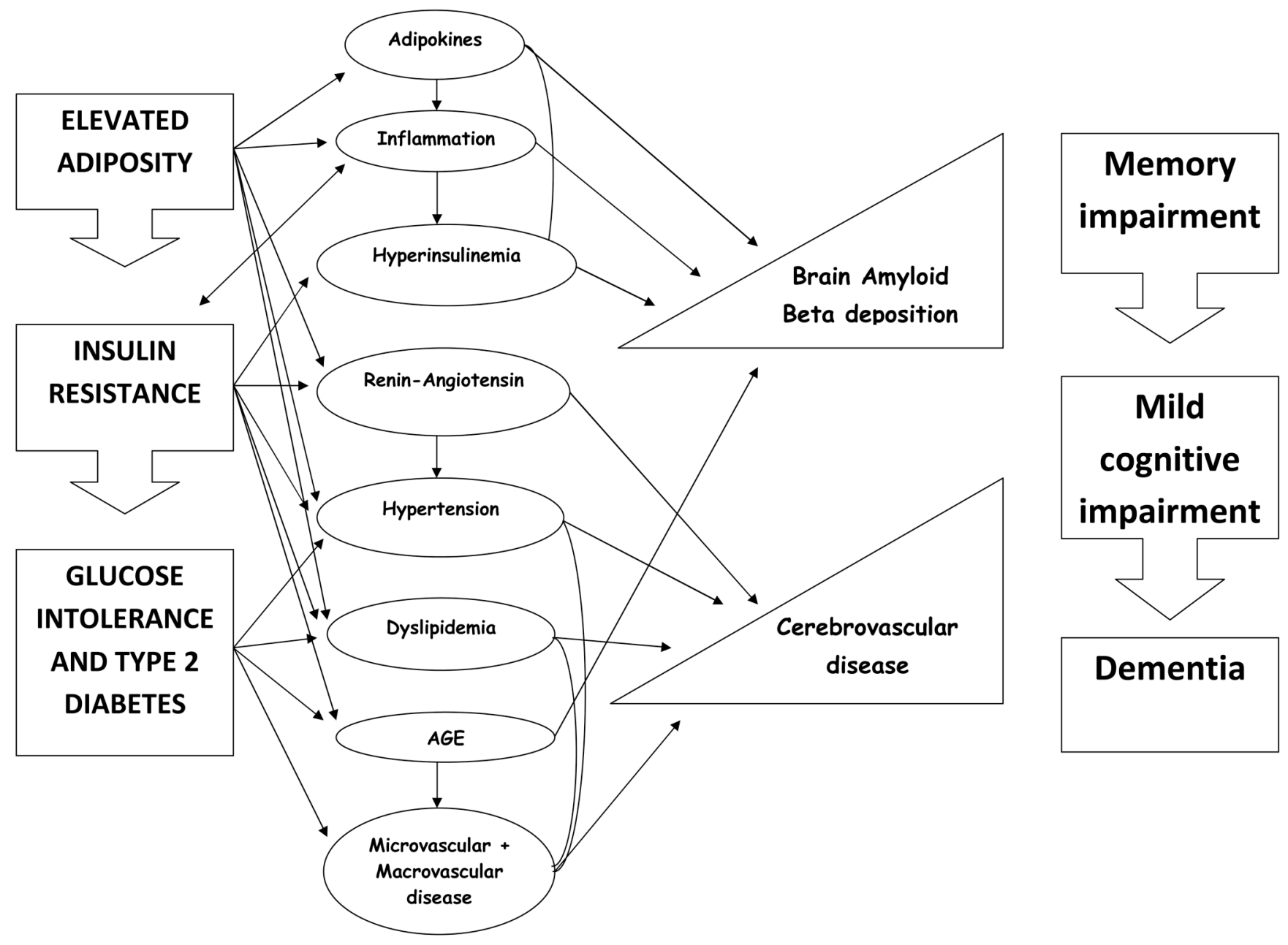

Figure 1.

Mechanism linking the continuum of adiposity, insulin resistance and type 2 diabetes to the manifestation of Alzheimer's disease. Elevated adiposity leads to insulin resistance which precedes most cases of glucose intolerance and type 2 diabetes. Each of these conditions is related to specific mechanistic intermediaries, but most mechanisms are shared. For example, elevated adiposity, insulin resistance, and type 2 diabetes are all accompanied by hypertension and dyslipidemia. In addition, some of these mechanisms are bidirectional. For example, insulin resistance due to elevated adiposity results in increased inflammation which in turn increases insulin resistance. These mechanisms overlap and are highly correlated. In theory, these mechanistic intermediaries result in increased amyloid beta deposition and cerebrovascular disease. Cerebrovascular disease is thought to decrease the threshold at which amyloid deposition causes the manifestations of Alzheimer's disease, which starts with memory impairment, reaching the threshold of mild cognitive impairment, and eventually dementia. 